2018

\title{
Quantitative Literacy: Now More Than Ever
}

Gail O. Mellow

LaGuardia Community College, GMELLOW@lagcc.cuny.edu

Follow this and additional works at: https://digitalcommons.usf.edu/numeracy

Part of the Adult and Continuing Education Commons, Curriculum and Instruction Commons, Higher Education Commons, and the Science and Mathematics Education Commons

\section{Recommended Citation}

Mellow, Gail O.. "Quantitative Literacy: Now More Than Ever." Numeracy 11, Iss. 2 (2018): Article 1. DOI: https://doi.org/10.5038/1936-4660.11.2.1 


\title{
Quantitative Literacy: Now More Than Ever
}

\begin{abstract}
This editorial highlights the eloquent words of Drs. Bernard Madison and Lynn Arthur Steen who, in the inaugural issue of Numeracy, note that quantitative literacy (QL) provides "tools for survival" in a highly competitive world. I discuss how QL is desperately needed at a precarious time for our nation's democracy and how at LaGuardia Community College, and community colleges across the nation, important and creative work is being undertaken to build students' math skills. The pivotal role of faculty is discussed and a call is made for colleges to support faculty as they undertake the challenging work of building QL skills for students who confront myriad obstacles in completing their degree. I conclude with a call for recognition of math faculty and the National Numeracy Network for undertaking the difficult work of delivering to students these essential "tools for survival."
\end{abstract}

\section{Keywords}

quantitative literacy, community colleges

Creative Commons License

$$
\text { (c) (1) (9) }
$$

This work is licensed under a Creative Commons Attribution-Noncommercial 4.0 License

\section{Cover Page Footnote}

Gail O. Mellow has served as President of LaGuardia Community College of the City University of New York since 2000. A vocal leader within and advocate for the nation's community colleges, Dr. Mellow has written extensively on the unique mission of community colleges within American higher education.

Among many leadership roles, she serves as a consulting editor for Change magazine. Dr. Mellow earned her MA dn PhD in Social Psychology from George Washington University. 
When I was approached by the editors of Numeracy and the leadership of the National Numeracy Network (NNN) to write an editorial, I must admit I was intrigued.

As any scholar would, I figured the best place to start is the beginning. I went to the inaugural issue of Numeracy, and, even though — or perhaps, especially as - a non-mathematician, I was immediately struck by the words of Dr. Bernard Madison and the late Dr. Lynn Arthur Steen:

Although the roots of quantitative literacy (hereafter, QL) extend back centuries, demand for QL in its present form has taken shape only in recent decades. In a very real sense, the need for a high level of quantitative literacy is an American characteristic, reinforced by individual freedoms, economic competitiveness, and the lack of economic safety nets. QL offers tools for survival in a Darwinian society. (Madison and Steen 2008, 2)

I know that "wow" isn't a very scholarly phrase, but I was "wowed" by the passion, the sense of social justice, and the urgency with which they, and presumably Numeracy readers and NNN members, approach quantitative literacy.

Your work, to provide "tools for survival," has never been more important. We live in a precarious time. Science is ridiculed, facts are dismissed as "fake news," and basic foundations of our democracy are being challenged. QL skills are essential for every role in our society - consumer, citizen, student, laborer, manager, or entrepreneur - to make sense of our increasingly complex world.

At LaGuardia Community College of the City University of New York, where I serve as president - a large, urban two-year public college located in the borough of Queens in New York City-I have had the great pleasure to watch the leadership of our innovative faculty design and teach curricula that places a central emphasis on building students' capacities for QL. As an open-access institution, we have a vast array of educational programs for our 45,000 students that strive to meet students' educational and career aspirations whether they are seeking a high school equivalency degree, a certificate in one of our workforce development programs, or an associate's degree. ${ }^{1}$ Integrated into all our work is our desire to build the numeracy skills of every student.

Our mathematics faculty have been at the forefront of the effort to align the numeracy skills of students to their majors and career plans. For our nursing students, for example, QL means mastering algebra and pre-calculus; for our social science majors, the emphasis is statistics.

In our Bridge to College and Careers Program ${ }^{2}$, through which adult learners earn a high school equivalency degree and gain entry into an entry-level job or the college, we teach math contextualized to a student's career aspiration. Students interested in health care learn percentages in the context of the administration of

\footnotetext{
${ }^{1}$ To learn more about the make-up of our student body, see our institutional fact sheet: http://www.laguardia.edu/uploadedFiles/Main_Site/Content/About/Docs/Fast\%20Facts.pdf

${ }^{2}$ https://www.laguardia.edu/bridge-to-college-and-careers-program/
} 
medication, while those hoping to enter a business-related career may learn the same concepts in the context of stock prices and revenue growth. The results of LaGuardia's Bridge program have been deservedly heralded: Bridge students are twice as likely to earn a high school equivalency credential and three times as likely to enroll in college in comparison to their peers in traditional programs. ${ }^{3}$

Similar efforts have been undertaken to connect math to compelling currentday issues for our associate's degree students. We've had faculty working with students to examine carbon dioxide emissions, understand which automobiles use less gas, and learn how to use math to comprehend the obesity epidemic. (To learn more, see the Spring 2014 issue of In Transit, the publication of LaGuardia's Center for Teaching and Learning.)

This work requires a level of flexibility and cooperation among many divisions in our college. Curricula and program requirements need to be developed - requiring a deep and sustained dialogue and collaboration between faculty in different departments. Mathematics faculty then must adapt their teaching as they seek to connect their teaching of core mathematical concepts to a different context and to a range of students with varying math skills and needs.

The math faculty that I encounter have a sense of urgency that we need to reimagine how students can gain QL. With more than $60 \%$ of all students nationwide entering community colleges needing developmental math, there's an imperative to designing approaches that move students more effectively and quickly through these essential courses. Math faculty at LaGuardia, and at many campuses, have responded. Course offerings and instruction have been redesigned to help students achieve success in their introductory math courses, removing a significant barrier to graduation for many community college students.

An important step has been recognizing that defining a uniform kind of math that's right for every profession isn't necessary. At LaGuardia we needed to look at how to reform our mathematics requirement in a way that provides all students with QL-but doesn't keep every student in locked step as if they're all physics majors.

Transformative change requires buy-in from all parties, particularly among faculty. It is the faculty, both full- and part-time, who need to be fully engaged in developing the new course offerings, designing pedagogy to support student learning, and identifying the learning students need to succeed. Faculty need comprehensive support to develop solutions, rather than too-often unrealistic ideas imposed on them from policymakers or campus administration.

As described in Taking College Teaching Seriously: Pedagogy Matters! (Mellow et al. 2015), a book about the importance of quality teaching to college

\footnotetext{
${ }^{3}$ To learn more, consult the program's webpage: https://www.mdrc.org/project/laguardias-ged-
} bridge-health-and-business-program\#overview. 
students' success, we need to invest in faculty development. Colleges need to support faculty to have the time and energy to explore, reflect on, and improve their pedagogy.

Too often, colleges expect the impossible. Typically, math faculty come to us having mastered advanced and abstract concepts of math. They've excelled in their research and are now expected to teach — and teach students with many challenges - often having neither the background or teaching expertise that is required. We ask them to teach math very differently than they've been taught. It is truthfully absurd.

It's why I've spent time thinking and writing about pedagogy recognizing that key ingredients - reflection on one's teaching, building of community amongst faculty, and coaching - are necessary components to successfully assist faculty to become better in their teaching. It's also why we, at LaGuardia, place great value on and invest considerable resources in the College's faculty development work, honoring scholarship that focuses on teaching and learning as much as we laud research into pure mathematical concepts.

In the subject of mathematics, it's critical that faculty be empowered, honored, and supported as they seek to do what is truly almost miraculous: take students who too often are fearful of math and help them overcome academic obstacles and gain math proficiency.

The challenge math faculty face is formidable. In an atmosphere where resources are limited (few community colleges receive adequate public or private support), where students face the everyday challenges of poverty and work and family obligations, we ask professors to help students achieve quantitative literacy. What's inspiring is to see the work of faculty - at LaGuardia Community College and what I see throughout the National Numeracy Network-impart the knowledge and skills that empower our students to be smarter and more engaged citizens of the world. Nothing is more important. I stand in awe of your work and your commitment as you truly are a force for social justice, providing students with the "tools for survival" required to build a stronger and healthier society.

\section{References}

Madison, Bernard L. and Lynn Arthur Steen. 2008. "Evolution of Numeracy and the National Numeracy Network." Numeracy 1(1): Article 2. https://doi.org/10.5038/1936-4660.1.1.2.

Mellow, Gail O., Diana D. Woolis, Marisa Klages-Bombich, Susan Restler, and Rosemary Arca. 2015. Taking College Teaching Seriously: Pedagogy

Matters! Sterling, VA: Stylus Publishing, LLC. 